\title{
A IMPORTÂNCIA DOS JOGOS PARA A CONTEXTUALIZAÇÃO DA DISCIPLINA DE HISTÓRIA NO ENSINO FUNDAMENTAL II
}

\author{
Shirley Rodrigues do Nascimento' \\ Ana Enedi Prince ${ }^{2}$
}

Resumo: O presente artigo versa sobre a importância em se trabalhar com práticas e recursos metodológicos e diversificados em sala de aula. Dentre eles, optamos no desenvolvimento de um jogo associado a um conteúdo curricular de História, voltado para alunos do Ensino Fundamental II. A concepção e a elaboração do jogo proposto devem ser realizadas em parceria com os alunos, fundamentada na concepção denominada de contrato didático pedagógico. A partir do momento em que é realizada essa parceria, os alunos passam a ter interesse e motivação. Os jogos trabalhados em sala de aula devem sempre ser elaborados e desenvolvidos de acordo com a temática proposta provenientes e associados aos conteúdos curriculares de História, propostos para a Educação Básica. A utilização de jogos no ensino de História proporciona um ensino contextualizado e eficiente de maneira lúdica.

Palavras-chave: Recurso didático; Jogos; Ensino de história.

\footnotetext{
${ }^{1}$ História/Universidade do Vale do Paraíba, Campos do Jordão, Brasil. E-mail: shirleyrodrigues138@gmail.com.

2 História/Universidade do Vale do Paraíba, Campos do Jordão, Brasil. E-mail: prince@univap.br.
} 